\title{
Study on the Relationship between the Autonomous Learning and English Learning Strategy
}

\author{
Haiyan Yan \\ Shandong Yingcai University, Ji'nan, 250104, China
}

\begin{abstract}
Keywords: Autonomous learning. English learning strategy. Interactive learning
\end{abstract}
\begin{abstract}
The idea of autonomous learning came into being with the change of the teaching mode. And against the background of the increasing requirement of students' comprehensive language ability in college English teaching, autonomous learning has become more and more important. In order to adapt to the characteristics of the contemporary English learning, more learning strategies and changing students' learning philosophy and way of thinking are of great necessity. Through classifying and analyzing English learning strategies, this paper tries to figure out the relationship between the autonomous learning and English learning strategy, thus to propose related learning strategy to further increase independent thinking in English learning.
\end{abstract}

\section{Introduction}

In today' s English teaching, the concept and idea of autonomous learning is wildly used and has gain good results. Especially for the learning of language, learning strategy and learning philosophy exert crucial effects on the efficiency of language learning. During the change of the traditional teaching mode, its importance is even more significant. Therefor, it is of great importance to pay attention to English learning strategy and reflect learning autonomy in the learning process in today' s English learning.

\section{Study of English learning strategy}

\section{Analysis of the concept of learning strategy}

Learning strategies are the ways to accept knowledge and information took by learners in the process of learning, and different learning strategies have different effects. Beside, good study strategy can not only improve the learning efficiency of learners, but also help to accept more and systematic information in the long run. In the course of formulating and choosing learning strategies, it is the learning philosophy that determines the leaner' $s$ learning strategy. Different learning philosophies lead to different leaning strategies. For instance, the one with the concept of autonomous study tends to rely on the self-oriented learning strategy, while those who have inspiring ideas often depend on the instructor to start their learning process. Learning languages such as English, it will have extremely negative effects if the learners have no good learning strategies. To make a proper learning strategy, it is necessary to understand the definition of learning strategies. First of all, the purpose of learning strategy is to learn a second language specifically, including not only the learning methods, but also learners' cognition of language learning. For example, the understanding of the characteristics of English learning, the plan and grasp of English learning process, these are all the problems that need to be solved before starting English learning. Secondly, the learning strategy also includes the principle of English learning, and understanding these principles will make it easier for learners to adapt to the characteristics of English learning and to further improve the learning efficiency. Last but not least, setting learning goals, and strategies used to plan, regulate and evaluate the learning process and learning results, as well as the learners' awareness of English learning are also belong to the category of English learning strategies. 


\section{An simple classification of English learning strategies}

English learning strategy can be simply divided into cognitive strategies and management strategies, among which cognitive strategies include cognitive strategies in the learning process and meta-cognitive strategies at the macro level. First of all, the cognitive strategy mainly refers to the specific learning methods, such as copying, taking notes, oral, recite, outlining that embodied in the learning process. The formulation of these strategies are based on unified learning plan and management objective, however, meta-cognitive strategies are adopted at a more macro level. Meta-cognitive strategies include planning strategy, monitoring strategy and regulation strategy, which can help the development of learning plan and provide macro guidance to the learning process. If the general direction is wrong, the learners will get half the result with twice the effort. What' $s$ more, management strategies contain the time arrangement and the methods to gain learning resources, such as improving the learning efficiency with the help of teachers, internet and cooperation. Understanding the classification of English learning strategies is very meaningful. Only with a good commanding of the classification of English learning strategies, can the learners perfect his or her learning strategy and employ scientific and reasonable learning plan and learning methods, which will ultimately improve the efficiency and effects of learning.

Table 1 Classification of English learning strategy

\begin{tabular}{|c|c|}
\hline \multirow[t]{3}{*}{ Cognitive strategy } & $\begin{array}{l}\text { Rehearsal strategy, such as repetition, copying, note-taking and } \\
\text { lineation }\end{array}$ \\
\hline & $\begin{array}{l}\text { Fine processing strategy, such as imagination, dictation, summary, } \\
\text { note-taking, analogy, answering questions }\end{array}$ \\
\hline & $\begin{array}{l}\text { Organizational strategy, such as chunking, picking main points, } \\
\text { outlining, drawing maps and so on }\end{array}$ \\
\hline \multirow[t]{3}{*}{$\begin{array}{l}\text { Mate-cognitive } \\
\text { strategy }\end{array}$} & $\begin{array}{l}\text { Planning strategy, such as setting goals, browsing, setting } \\
\text { questions, etc. }\end{array}$ \\
\hline & $\begin{array}{l}\text { Monitoring strategy, such as self check, concentration, } \\
\text { re-examination, adopting application strategy, etc. }\end{array}$ \\
\hline & $\begin{array}{l}\text { Regulation strategy, such as adjusting reading speed, re-reading, } \\
\text { re-examination, adopting application strategy, etc. }\end{array}$ \\
\hline \multirow{3}{*}{$\begin{array}{l}\text { Resource management } \\
\text { strategy }\end{array}$} & Time management, such as building a schedule and setting goals \\
\hline & $\begin{array}{l}\text { Effort management, such as effort-oriented, psychological } \\
\text { adjustment, self talk, persistence, self-reinforcement }\end{array}$ \\
\hline & $\begin{array}{l}\text { Others' supports, such as asking teachers and friends for help, } \\
\text { group work and tutorial }\end{array}$ \\
\hline
\end{tabular}

\section{The relationship between the autonomous learning and English learning strategy}

\section{Analysis of the contents of autonomous learning}

To analyze the relationship between the autonomous learning and English learning strategy, it is necessary to have a clear understanding of the concept of autonomous learning. The concept of autonomous learning is based on self-learning method. With the course teaching reform, the importance of autonomous learning is becoming more and more evident. Autonomous learning has the following main contents. The first is the ability to use learning strategies, which means merely understand English learning strategy is not enough, because understand is not application. And the good ability of practice depends on the learners' concept of learning. The second is the external environment of learning, mainly including the teacher resource, teaching methods as well as the external pressure and motivation of the learners. Teaching methods play an important role in the formulation of autonomous learning concept. Nowadays, the advocated autonomous learning emphasizes that the students are the main body and the teachers act as guide and counselor. By correct guidance and good external environment, learner can carry out English learning 
independently in order to stimulate students' autonomy and enthusiasm. The third refers to the interactivity of the learning process. Autonomous learning dose not mean learning alone or independent leaning. Besides, as a language, English is an applied and practical learning program. Therefore, it is of great necessity to lay stress on the interactivity in the learning process and to achieve the goal of training and improving through communication. All in all, autonomous learning has a relatively rich and wide range of content, and understanding the content of autonomous learning is beneficial to formulating and choosing a scientific and reasonable English learning strategy.

\section{The mutual conditionality between learning autonomy and English learning}

Autonomous learning depends on the learners' cognition of English learning, and the cognitive strategy always influences the choice of learning management and executive strategy. As shown below:

Fig.1 The relationship between cognitive strategy and learning strategy

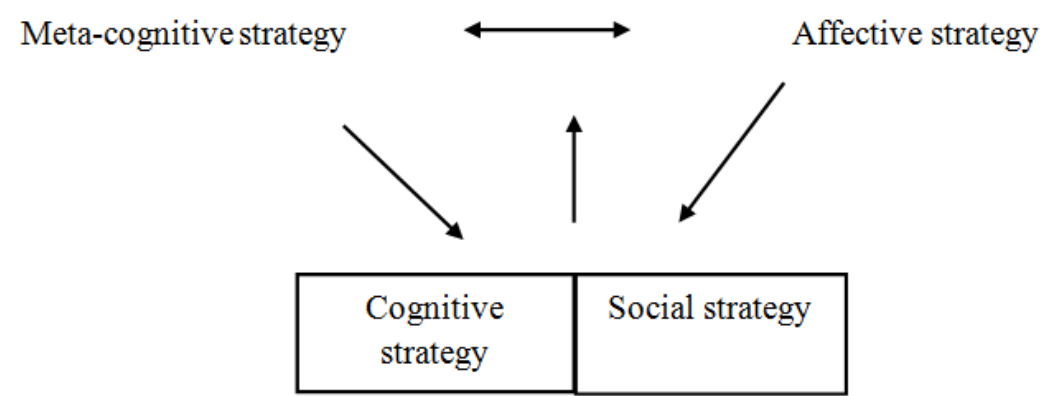

The figure above reflects the mutual influence and mutual conditionality between learning philosophy and learning strategy, of which the formation of the concept of autonomous learning can affect learners' emotional strategies and meta-cognitive strategies. And this is specifically embodied in the practical English learning methods. It is worth mentioning that, due to the nature of English language, only through listening, speaking, reading, writing, translating and other trainings, can learners achieve the overall rise in the English ability. Consequently, social strategy also affects the English learning, so the way and extent of exchanges and cooperations between learners also determine the English learning efficiency to a large degree. However, American scholar Benson Volar argues that the success of the learning activities in a sense depends on learners' attitude towards the world, especially the attitude towards learning activities. The learners' attitude to himself or herself, their learning desire to master different language skills and the specific learning strategies that can be used consciously and observed are called learning skills. His opinions are more focused on learners' self-awareness, and he thinks the external environment is changed with the' learners choice of learning concept and learning strategy. Thus, to a large extent, autonomous learning philosophy and learning strategy are mutually influenced and conditioned. With the guidance of autonomous learning philosophy, learners will pay more attention to the importance of autonomous learning, and the acquirement of external learning resource, which will result in the change of learning strategy. Learners will attach great importance to the communication and cooperation with other and the reflection of the characteristics of English learning in the process of learning, which has a practical significance for learners to make impeccable study plans.

\section{The diversity of English learning strategy from the perspective of autonomous learning}

English learning involves five main aspects, which are listening, speaking, reading, writing and translating. From the perspective of autonomous learning, each aspect has different learning strategies, that is the diversity of English learning strategy. Moreover, diversified English learning strategy is of great importance to improve the learning effects. After all, the single learning strategy tends to have many limitations, and its applicable scope is relatively limited. Hence, to realize autonomous learning requires the help of diversified English learning strategy. Use the reading and listening of English learning as an example, the influence of autonomous learning concept on the English learning strategy is clearly showed to all. The following table lists the strategies for English vocabulary learning and listening training. Learning vocabulary includes many learning strategies, 
such as memorizing, association, reading, using dictionaries and so on. In the process of learning English vocabulary, it shall be remembered that comparison, contrast and quotation rather than memorizing mechanically are more effective in remembering words. Only with a good command of vocabulary, can we read English fluently. The same goes to listening training, but it pays more attention to exchanges and cooperation, and better learning effect can be achieved in specific language environment.

Table 2 Strategies for English vocabulary learning

\begin{tabular}{|c|c|}
\hline Memory strategy & Make a list of vocabulary and memorize mechanically \\
\hline Practicing strategy & $\begin{array}{l}\text { Do single vocabulary practice and make comparison } \\
\text { and recognition of vocabularies }\end{array}$ \\
\hline Reciting strategy & Memorize vocabulary through reciting targeted passage \\
\hline Consulting dictionary strategy & $\begin{array}{l}\text { Consult the dictionary when necessary to understand } \\
\text { the meaning and take notes }\end{array}$ \\
\hline Collocation strategy & Learn vocabulary through fixed phrases and idioms \\
\hline Word-formation strategy & $\begin{array}{l}\text { Learn vocabulary with the help of etymology, root, } \\
\text { affix and other word-formation knowledge }\end{array}$ \\
\hline Context strategy & Learn vocabulary through reading the context \\
\hline Guessing strategy & $\begin{array}{l}\text { Guessing the polysemant and new words with the given } \\
\text { information in the context }\end{array}$ \\
\hline Categorization strategy & $\begin{array}{l}\text { Categorize the vocabulary into different semantics and } \\
\text { pragmatics }\end{array}$ \\
\hline Association strategy & $\begin{array}{l}\text { Use association by contiguity (space and time), } \\
\text { association by contrast, association by similarity } \\
\text { (characteristics) to memorize, recall and use words }\end{array}$ \\
\hline
\end{tabular}

Tabl 3 Strategy for English listening

\begin{tabular}{|l|l|}
\hline Pre-listening strategy & $\begin{array}{l}\text { Before listening the material, listen to the related material to activate } \\
\text { related graphics and improve the listening effects }\end{array}$ \\
\hline Aural image strategy & Build the images of the listening material in mind while listening \\
\hline Arrangement and categorization strategy & $\begin{array}{l}\text { Use notes, information loss and thematic framework to make a clue } \\
\text { chain }\end{array}$ \\
\hline Deduction strategy & Use the given clue to deduce a conclusion \\
\hline Selective attention strategy & Pay attention to the key words, sentences and specific questions \\
\hline Association strategy & $\begin{array}{l}\text { Combine the information get form the listening material with } \\
\text { existing knowledge schema, thus to play an active role of the } \\
\text { listening results }\end{array}$ \\
\hline Situation strategy & $\begin{array}{l}\text { Get as much as possible touch with the words used in multimedia } \\
\text { communications }\end{array}$ \\
\hline Interactive listening strategy & $\begin{array}{l}\text { Maintain two-way and multi-exchanges to accelerate the formation } \\
\text { of discourse competence, sociolinguistic competence and strategic } \\
\text { competence }\end{array}$ \\
\hline
\end{tabular}

To put autonomous learning into practice calls for a variety of English learning strategies. And diversified learning strategies is not only determined by the characteristics of English learning, but also the foundation of autonomous learning. The advantages of English learning strategies can only be reflected when learners take the initiatives, have learning enthusiasm and stick to the learning methods.

\section{The embodiment of the autonomous learning and English learning strategy}

\section{The formulation of plans and goals of English learning}


The development of autonomous learning requires learners to draw up learning plans and goals according their own learning characteristics. Based on the understanding of the characteristics of the English learning, selective use of related English learning strategies to complete learning activities will have a better effect. And to work out a scientific and rational learning plan, learners need to understand their own learning needs, which is a full understanding of their actual English level and expected level. In this process, teachers can offer proper guidance and help learners make reasonable analysis of themselves by setting analytic problems. In addition, currently there is another type of study plan formulation, namely "consultative program" (Negotiated syllabus). To be specific, it means that students and teachers cooperate together to make a rational learning program before learning activities, in which teachers can play a good role in assistance. Study programs made in this way not only conform to the objective conditions, but also can meet the learners' subjective needs.

\section{The choice of English learning content}

The choice of learning content refers to learners' autonomous choice of content that accords with the learning program, thus to further promote English learning activities. Initiative is needed in the learning process. However, it is very difficult for teachers to improve students learning initiative. It can only be achieved through indirect ways, such as choosing teaching content that students are interested in, or adopting non-traditional teaching modes to stimulate students' learning enthusiasm. In a word, the principle of choosing English learning contents is to respect learners' characteristics, and only based on individuation, can teachers stimulate students learning initiative. Student-oriented is emphasized in English learning, which means that learners have more choices and rights in selecting learning content. Based on their own learning interest and development direction, learners can choose some specific fields to carry out their studies, namely listening, speaking, reading, writing and translation. In this way, it can not only reflects learners' learning initiative, but also make sure leaners' autonomy.

\section{The realization of the learning process}

Throughout the learning process, supervision and management strategies are of great necessity, including the supervision and management before, during and after learning activities. Specifically, the first is the learner's study plan and preparation, the latter mainly refers to mental preparation. Learners must have a clear awareness that learning is a long-term process, so they have a long-term attitude towards English learning. Secondly, in the learning process, autonomous learning is reflected in the cooperation with others. Through exchanges and cooperation, learners can not only find their own shortcomings, but also have more in-depth understanding of the characteristics of English learning. For instance, with a better understanding of their own weakness and strength, learners can learn from others' strong points to offset their weakness and achieve a perfect combination of learning philosophy and learning strategy. Last but not least, it is about the learning evaluation. By means of objective evaluation, teachers must not only look at the ultimate learning results, but also pay attention to learners' learning efforts. Only with scientific and reasonable supervision and management strategy, better English learning strategies can be achieved to reach the best English learning effect.

\section{Conclusion}

To conclude, Learning strategy is the embodiment of autonomous learning, and the concept of autonomous learning is the guidance of learning English. Autonomous learning method can give full play to the learners' learning initiative, while diversified learning strategy can also help English learning, which makes the learners go less detours and improve the efficiency of English learning. Through making scientific and rational learning plans and careful selection of learning, English learning will be more specific. On this basis, the process of learning English is enriched, and the effective English language learning is finally realized.

\section{Acknowledgments}


This paper is the research findings of Shandong social science planing issues, the name is Research on the Relation Between the Independent Study and College Students English Comprehensive Ability(NO.:11CWZJ45) .

\section{References}

[1] Aoki, N: Affect and the role of teachers in the development of learner autonomy. Arnold J (ed.). Affect in Language Learning[C]. Beijing: foreign language teaching and Research Press, 2000:142-154.

[2] Benson, P \&P. Voller: Autonomy and Independence in Language Learning. London: Longman, 1997.

[3] Bialystok E: A theoretical model of second language learning [A]. Kenneth Croft. Readings on English as a Second Language[C].2nd edition, Boston: Little, Brown and Company, 1980.

[4] Wen, Qiufang: Differences of Learning Methods between English winners and English losers, Foreign Language Teaching and Research, 1995(3).

[5] Zhang,Yongsheng: Communicative Strategy and Group Discussion, English Language World, 2003(2). 